\title{
ШЛЯХИ ПОКРАЩЕННЯ НАВЧАННЯ 3 МЕТОЮ ПОПЕРЕДЖЕННЯ ПСИХОЕМОЦЙНИХ ПОРУШЕНЬ У СТУДЕНТІВ-МЕДИКІВ ВИЩИХ МЕДИЧНИХ ЗАКЛАДІВ
}

\author{
S. V. Bobruk \\ M. Pyrohov Vinnytsia National Medical University
WAYS OF IMPROVING EDUCATION WITH THE AIM OF PREVENTION OF PSYCHO-EMOTIONAL VIOLATIONS IN MEDICAL STUDENTS OF \\ HIGHER MEDICAL INSTITUTIONS
}

\begin{abstract}
Мета роботи - проаналізувати фактори негативного впливу, які виникають під час навчального процесу у студентів-медиків, та полегшити вивчення і закріплення матеріалу.

Основна частина. Проаналізовано умови навчання студентів-медиків Вінницького національного медичного університету ім. М. І. Пирогова. В ході роботи було встановлено, що одними з основних труднощів, із якими зіштовхуються майбутні лікарі, - це необхідність засвоєння великого об’єму навчального матеріалу за короткий період часу та відсутність відпочинку. Створення кімнат для відпочинку між заняттями чи після них та викладення матеріалу у вигляді рольових ігор забезпечать краще вивчення і засвоєння не тільки теоретичного, а й практичного матеріалу та покращать психоемоційний стан студентівмедиків. Перспективною є також робота зі студентами спеціаліста в галузі психології, який, у свою чергу, зможе вчасно виявити та надати допомогу студентам, які входять у групу ризику щодо психоемоційних розладів.

Висновки. Підвищення продуктивності навчання студентів-медиків можна досягти шляхом впровадження в практику викладання матеріалу у вигляді рольових ігор. Це дасть можливість викладачу оцінити та закріпити знання одразу усієї групи студентів, серед яких здорова конкуренція слугуватиме мотивацією до кращого навчання. Вирішити ряд проблем, які виникають з боку порушення психоемоційного здоров’я, можна створенням умов для отримання кваліфікованої допомоги психолога, що сприятиме легшому перебігу адаптації до навантаження.
\end{abstract}

Ключові слова: психоемоційні порушення; студенти-медики; мотивація.

The aim of the work - to analyse the factors of negative influence, that arise up during an educational process for medical students and to facilitate a study and consolidation.

The main body. The conditions of training of medical students of Vinnytsia National Medical University by M. I. Pyrohov were analyzed. During the course of the work, it was found that one of the main difficulties faced by future physicians is the need to absorb a large amount of educational material in a short period of time and lack of rest. Creating rooms for recreation between classes or after them and the presentation of material in the form of role-playing games will provide a better study and mastering of not only theoretical and practical material and improve the psycho-emotional state of medical students. Perspective is also the work with students of a specialist in the field of psychology, which, in turn, will be able to identify and provide assistance to students in the psychological and emotional disorder risk group in a timely manner.

Conclusions. Improving the performance of medical students' training can be achieved by introducing into practice the teaching of material in the form of role-playing games. This will enable the teacher to evaluate and consolidate the knowledge of the entire group of students at once, among which healthy competition will serve as a motivation for better learning. To solve a number of problems that arise from the violation of psycho-emotional health can be created conditions for obtaining qualified assistance from a psychologist, which will facilitate the easier flow of adaptation to the load.

Key words: psycho-emotional disturbances; medical students; motivation.

Вступ. У сучасних умовах інтеграції освіти України, з передовими освітніми технологіями, особливої ваги набуває питання забезпечення якісного вивчення студентами медичних вишів, незалежно від їх державної приналежності, усіх дисциплін, що

(C) С. В. Бобрук викладаються протягом навчального циклу. Адже професійна компетентність майбутніх лікарів напряму залежить від рівня знань та оволодіння практичними навичками. Окрім цього, для виховання високопрофесійних спеціалістів досить важливими $\epsilon$ мотивація та сформована самооцінка студента. Як 
складне особистісне утворення, що належить до фундаментальних психологічних властивостей людини, самооцінка формує конкурентоспроможність $[1,2]$. Порушення самооцінки щодо власної професійної компетенції у той чи інший бік негативно позначається на психологічному стані та, відповідно, на кінцевому результаті діяльності. Психоемоційне здоров’я людини є досить важливою складовою у формуванні особистості, яка в умовах сьогодення має бути соціальною та затребуваною. Професія лікаря направлена на допомогу, при цьому сам лікар має чітко усвідомлювати свій внесок у суспільство без самопожертви з боку свого власного здоров'я.

Мета роботи - пошук способів покращити навчання студентів-медиків із метою зменшення стресогенності та попередження розвитку психоемоційних розладів.

Основна частина. В умовах реформування освіти в Україні студенти-медики перших років навчання відчувають велике навантаження та відповідальність, що тягне за собою постійний психологічний тиск та емоційне виснаження [3]. Великий об’єм матеріалу, нестача часу та відсутність відпочинку відображаються у хронічній втомі, яка призводить до депресії, зневіри у власних силах та, як наслідок - суїцидальних думок та намірів. Зростання рівня стресогенності в ході навчання знаходить своє відображення в багатьох соматичних захворюваннях вже на більш старших курсах і призводить до формування психологічно нестабільної нації лікарів.

Небажані наслідки психоемоційного навантаження краще профілактувати, аніж лікувати. Досить цікавою практикою у рішенні цих проблем є створення кімнат для відпочинку та зняття стресу. Обов'язковою умовою, окрім ретельно підібраного інтер’єру, є послуга спеціаліста у сфері психології, адже, часто, студенти не можуть відкритися одноліткам та “закриваються” у собі. Наявність таких кімнат забезпечуватиме, окрім відпочинку, ще й належну консультацію спеціаліста та допомагатиме окреслити коло “проблемних” студентів, які шляхом вчасного виявлення будуть проходити кур- си відповідного лікування з метою попередження небажаних наслідків.

Іншою проблемою є викладання великої кількості матеріалу за короткий час заняття. Аналізуючи методи підготовки лікарів у вищих медичних закладах, слід відмітити основні ланки спрямованості на теоретичне викладення матеріалу протягом заняття, роботу з симуляційним допоміжним інструментарієм та навчання біля ліжка хворого на клінічних базах [4]. Важкість поєднання великого об’єму теоретичного матеріалу з практичними вправами призводить у студентів до швидкої втоми та незасвоєння матеріалу. Альтернативою може слугувати ведення заняття у вигляді гри, коли одночасно залучаються знання усієї групи, поєднуються теоретичні та практичні навики [5]. Під керівництвом викладача студенти, відповідно до рівня вивченого матеріалу, створюють ситуацію та разом йдуть до її вирішення. Це дає можливість викладачу оцінити всіх учасників гри, зацікавити студентів вивченням предмета, а також створює умови для їх відпочинку [6].

Невід'ємним компонентом корисного навчання $\epsilon$ мотивація, що є прагненням людини реалізувати себе в тому, в чому вона здібна [7]. Саме вона забезпечує високопродуктивну працю. Тому студенти-медики, які показали найкращі знання та активність під час заняття, окрім оцінки, мають отримувати додаткові заохочення у вигляді балів на підсумковому модулі.

Висновки. В умовах реформування як галузі охорони здоров'я, так і освіти велику увагу слід приділяти психологічному здоров'ю студентів, які являють собою майбутню рушійну силу країни. Забезпечення належних умов навчання та відпочинку сприяє продуктивній підготовці висококваліфікованих спеціалістів у галузі медицини. Поряд із правильною організацією та викладенням тематичного матеріалу мотивація до навчання забезпечить правильний підхід до підготовки майбутніх лікарів.

3. Depression, anxiety, and perceived hassles among entering medical students / C. K. Smith, D. F. Peterson, B. F. Degenhardt, J. C. Johnson // Psychology, Health \& Medicine. - 2007. - Vol. 12, No.1. - P. 31-39.

4. Артьоменко В. В. Симуляційне навчання в медицині: міжнародний та вітчизняний досвід / В. В. Ар- 
тьоменко // Одеський медичний журнал. - 2015. - № 6 (152). - С. 67-74.

5. Козирєва Н. Ю. Рольова гра як один із засобів інтерактивного навчання / Н. Ю. Козирєва // Ученые записки Таврического национального университета им. В. И. Вернадского. Серия “Филология. Социальные коммуникации”. - 2012. - Т. 25 (64), № 1, ч. 2. С. 289-293.

\section{References}

1. Lomov, B.F. (2006). Psikhicheskaya regulatsiya deyatelnosti. Izbrannyye trudy [Psychic regulation of activity. Selectas]. Moscow: Izd-vo IP RAN [in Russian].

2. Yanshyn, P.V. (2007). Klinicheskaya psikhodiagnostika lichnosti. Uchebno-metodicheskoye posobiye [Personality clinical psychodiagnostics. Education and methodology guide]. Saint Petersburg: Rech [in Russian].

3. Smith, C.K., Peterson, D.F., Degenhardt, B.F., \& Johnson, J.C. (2007). Depression, anxiety, and perceived hassles among entering medical students. Psychology, Health \& Medicine, 12 (1), 31-39.

4. Artomenko, V.V. (2015). Symuliatsiine navchannia v medytsyni: mizhnarodnyi ta vitchyznianyi dosvid [Simulation learning in medicine: international and national experience]. Odeskyi medychnyi zhurnal - Odesa Medical Journal, 6 (152), 67-74 [in Ukrainian].
6. Івченко В. К. Про деякі проблеми практичної підготовки фахівців / В. К. Івченко, П. С. Меженський, O. I. Швець // Проблеми медичної науки та освіти. 2001. - № 3. - С. 32-33.

7. Maslow A. H. Motivation and personality / Abraham H. Maslow. - New York : Harper and Row, 1970. - 369 p.

5. Kozyrieva, N.Yu. (2001). Rolova hra yak odyn iz zasobiv interaktyvnoho navchania [Role-playing game as on of the means of interactive learning]. Uchenyye zapiski Tavricheskogo natsyonalnogo universiteta im. V.I. Vernadskogo. Seriya "Filologiya. Sotsyalnyye komunikatsyi" - Proceedings of Taurian National University by V.I. Vernadskyi. Series “Philology. Social communication”, 25 (64), 1(2), 289-293 [in Ukrainian].

6. Ivchenco, V.K., Mezhenskyi, P.S., \& Shvets, O.I. (2001). Pro deiaki problemy praktychnoi pidhotovky fakhivtsiv [Some problems of professionals' practical training]. Problemy medychnoi nauky ta osvity - Problems of Medical Science and Education, 3, 32-33 [in Ukrainian].

7. Maslow, A.H. (1970). Motivation and personality. New York: Harper and Row. 